\title{
EVALUATION OF DIMENSIONS, APPROACHES AND CONCEPTS OF RESILIENCE IN URBAN SOCIETIES WITH AN EMPHASIS ON NATURAL DISASTERS
}

\author{
M. R. Rezaei, A. Bastaminia* \\ Department, Yazd University, Yazd, Iran
}

Published online: 16 July 2016

\begin{abstract}
Despite the passage of more than three decades from conducting primary researches on resilience of cities, yet this concept lacks a comprehensive and operational understanding in various scientific fields, including disasters management. Most of existing contradictions on the meaning of urban resilience is resulting from cognitive tendencies, methodological methods, and existing basic conceptual differences, as well as viewpoints focusing on research in ecological, social systems or a combination of both.A city will be considered fully resilient when all indices, components and dimensions of resilience in that city to be placed in a better situation and are in growth and promotion mode. Perhaps an uneven promotion of different dimensions of turban resilience will not be much led to resilience of totality of a city and its people. Leading social - economic dimension as a dimension that has the most relationship with people and citizens is very important in resilience of cities. The aim of this research is to examine the social and economic dimensions, approaches and concepts of resilient city as one of the new approaches in the field of reducing vulnerability and promoting crisis management. This research is a review study, which has been collected and investigated and analyzed from various library and documentary resources.
\end{abstract}

Keywords: dimensions, approach, resilience, disasters, urban societies

Author Correspondence, e-mail: Abastami31@gmail.com

doi: http://dx.doi.org/10.4314/jfas.v8i2s.103 


\section{INTRODUCTION}

Natural disasters that are considered a part of human life process and the number and variety of them are being added every day have been posed as a basic challenge to achieve sustainable development of human societies (1). thus identification of methods to achieve sustainability has been entered into disasters planning and management through different patterns of reducing vulnerability, and has found an appropriate position in making national policies of each country to create ideal conditions for efficient and more effective reduction of risks at various levels of disasters management, especially earthquake management because of extensive damagees and widespread social abnormalities (2).

Extensive level of damages and casualties caused by natural disasters in various cities around the world including our country has caused that wide applied researches to be done in the field of optimizing immunization of cities. On the other hand, methods to deal with natural disasters and immunization of cities have made necessary the increas of efficiency of methods to deal with natural disasters and immunization of cities (3).

It is therefore evident that applied research on issues related to immunization of cities against natural disasters will increase initiatives in designs and finding the best policies (4)Policies and measures to reduce hazards are performed with two objectives: 1. Empowerment of community for resilience against hazards, while development activities do not increase vulnerability of community toward hazards. 2. Traditional hazard reduction plans and programs have focused on sustainability and strengthening of physical systems (5).

In this regard, many of the studies on the hazards that have been focused on flood, hurricane, earthquake, large fires, rain and frost and other extreme climatic events investigate this topic why people immigrate or move to crisis-prone regions? And how are their perceptions of risk? So the discussion is on the approach that links all dimensions and helps to understand uncertainty and also reduce the vulnerability, namely Resilience Approach (6). So, inclusion of programs of increasing resilience and reducing vulnerability of citizens and community that are subject to natural hazards and disasters in urban development plans is necessary to achieve this goal(7).

Generally there are two types of strategies for dealing with natural disasters, including forecast strategies and resilience strategies. the first one is used to encounter with problems and difficulties, and the latter to deal with unknown problems (8). Resilience among these is promotion of community's ability, planning and preparation for absorption and improvement and more success to deal with the unwanted effects after disasters and rehabilitation and 
improvement of the community hit by disaster socially, economically, environmentally, and physically (9).

Accordingly, link between community development, management and disasters management is essential for creation of resilient city against hazards. Planning based on community and hazards assessment and risk takings is initial fundamental step in creating resilience of cities. Programs should be regularly reviewed and updated based on new information and experiences and lessons learned from the implementation and supervision (10). So, resilience should be placed focal concept of all programs of disasters management and development in cities. Resilience has the capacity to be entered into natural disasters management cycle before, during and after a disaster (11).

Given that natural disasters management after occurrence of disaster has not been in desirable conditions in Iran, and after the occurrence of such events such as the earthquake in Bam and Roudbar the people of these communities have been highly damaged, and because people hit by disasters are not usually able to return to balanced conditions easily or change easily their conditions in a new way, and can achieve a successful compatibility (12), therefore evaluating dimensions, approaches and concepts of resilience in urban societies with an emphasis on natural disasters seems necessary.

\section{METHODOLOGY}

This research is a review that various library and Internet resources such as Science Direct, Proquest, CINAHL, Scopus, Google Scholar, Google, Magiran, IRANDOC and SID databases with Persian and English keywords of concept and definition of urban resilience, social resilience, economic resilience, resilience approaches, natural disasters, disasters management and crisis management were firstly searched in terms of combinatorial and separately. Inclusion criteria included Persian or English language of the article, insertion of words such as resilience in the title and / or keywords of the article and printing the article in domestic and foreign reputable journals. Proposed one-page studies and letters of editor were exclusion criteria.

It should be noted that there was no possibility to receive some articles completely because of existing limitations. This can be considered as the limitations of this study. Totally, inclusion criteria found and reviewed 136 articles and documentation of 66 related and valid articles were extractedfinally. 


\section{Definitions and concepts of urban resilience}

Urban resilience is a relatively new concept that still lacks a clear definition (13). The term resilience has been derived from biology discipline. A biological system is defined living creatures' ability to resist and recover against a shock, disaster, disease or other changes (14). The definition of urban resilience "generally refers to the ability of a city or urban systems and resistance against a set of widespread shocks and stresses (10). Urban resilience city can be considered as" the ability of a city against changes before reorganizing around a new set of structures and processes (15).

This shows the resilience of city, not only ensures a return to the previous state and / or balance but also the possibility of adapt to changes and further survival of the city (16). Arefi (17) argues that different parts of city show different kinds of resistance against changes. These changes in cities are often caused by economic, cultural and technological conditions (18). Cities are in an unstable and changing situation in a continuous process of internal changes, reduction and increase of connections, change of clusters and sectors (19).

Urban planners and policymakers should try to adapt space crises to various spatial, economic, and environmental and social global crises. Urban planning plays a crucial role in the formation of resilient cities. Strategic planning is essential to adapt to changes and crises to create a resilient city (10).

One of the advantages of planning for resilience of cities is that it does not need to focus on specific pattern of urban form, or urban development. This flexibility allows that accountability ability and ability to adapt to be existed considering the unique conditions of the cities and development programs. This causes that intellectual creativity to be created for thinking to gain resilience in different ways, without being restricted within a specific framework (20).

Society for Disaster Reduction (SDR, 2005) has stated resilient cities' characteristics as follows:

- Appropriate and relevant hazards are identified and understood.

- Resilient cities know when a risk is imminent.

- People are safe from hazards.

- Resilient communities experience minimum disturbance in the flow of life and their economic flow after passing through adventures (21).

- Resilient cities are ready cities. A resilient city quickly responds in unexpected conditions, adjusts if necessary, and continues its work despite the bad and uncomfortable 
conditions. Resilience in long-term requires a greater ability to rebound to the first place from the shock to the system, and requires the ability to adapt to subtle changes over time and development of the city in long-term and flexible way (22). Central buildings less crumble in resilient cities, and a power outage occurs less. Fewer families and commercial centers are at risk. In addition, a smaller number of deaths and injuries happen and less incoordination and communicational problems occur (23).

Table 1. Definitions and concepts of resilience of cities

\begin{tabular}{|c|c|}
\hline Holling 1995 (24) & $\begin{array}{l}\text { Urban resilience is further capacity or the ability of a city to digest disturbance or is the } \\
\text { amount of disturbance that a system can digest it before the system structure is changed by } \\
\text { changing variables. }\end{array}$ \\
\hline Buckle 2000 (25) & $\begin{array}{l}\text { Quality of people, communities, agencies, and infrastructure reduce vulnerability. Not only } \\
\text { lack of vulnerability but the capacity to prevent and reduce damages and then at the next } \\
\text { stage maintenance of ideal conditions in cities as much as possible in case of incidence of } \\
\text { harms, and then in third stage to recover from the effects. }\end{array}$ \\
\hline $\begin{array}{c}\text { Holling and } \\
\text { Gunderson } 2002(26)\end{array}$ & $\begin{array}{c}\text { The severity of disturbance that a city can absorb it before structure of cities to be converted } \\
\text { to a different structure through change in variables and processes that are controlled by } \\
\text { behavior }\end{array}$ \\
\hline Cardona2003 (27) & $\begin{array}{l}\text { Capacity of damaged cities or ecosystems to digest the negative effects and rehabilitate } \\
\text { them. }\end{array}$ \\
\hline UNISDR 2005 (28) & $\begin{array}{l}\text { Capacity of a city at risks to become adjusted, resist or change in order to reach an } \\
\text { acceptable level of operations and structure and its continuation. This is determined by a } \\
\text { degree that the social system is capable of organizing and increasing capacity, learning from } \\
\text { past disasters and improving assessments of reducing the possibility of its own risk. }\end{array}$ \\
\hline Cutter2010 (29) & $\begin{array}{l}\text { Urban resilience is called to absorption capacity and basic and special performances, as well } \\
\text { as capacity of recovery, "Return to Balance", after disaster. }\end{array}$ \\
\hline $\begin{array}{l}\text { Fathi and Arefi } 2012 \\
\text { (7) }\end{array}$ & $\begin{array}{l}\text { Urban resilience is the ability of biological systems and organisms to resist or return to } \\
\text { normal status against shocks, disasters, diseases, and other changes }\end{array}$ \\
\hline Turner 2013 (20) & $\begin{array}{l}\text { Change process of strengthening the capacity of population, communities, organizations, } \\
\text { and forecasting, prevention, recovery and change of cities after the occurrence of shock, } \\
\text { stress and changes. }\end{array}$ \\
\hline Birkmann 2013 (30) & $\begin{array}{l}\text { Urban resilience is considered "capacity of damaged communities or ecosystems to digest } \\
\text { the negative effects and rehabilitate them". }\end{array}$ \\
\hline Kärrholm 2014 (31) & $\begin{array}{l}\text { The severity of disturbances that a city can absorb it before structure of the system to be } \\
\text { converted to a different structure through change in variables and processes that are } \\
\text { controlled by behavior }\end{array}$ \\
\hline $\begin{array}{l}\text { Kutum and Al-Jaberi } \\
\qquad 2015 \text { (32) }\end{array}$ & $\begin{array}{l}\text { Resilience is called the capacity of cities to absorb disturbances and also to keep necessary } \\
\text { and inherent feedbacks, processes and structures of the city }\end{array}$ \\
\hline
\end{tabular}

There are two general points in definitions for resilience of cities: first, that resilience has been seen more as ability or current rather than a result. Second, resilience was thought more as compatibility rather than stability. In fact, stability (or failure in change) in some conditions can be considered as lack of resilience. For example, resilience of the systems depends on a component of the system that is able to change or adjust in response to changes 
in other components. Thus the system fails in practice, if it remains as the component of stability.

"Resilience engineering" makes possible the return of a city to the pre-designed status or the action after turbulence, while "ecological resilience" considers allowed most of possible desirable modes that are adapted to the environment. The second type of resiliency is probably the type suitable for human societies, organizations and cities. So resiliency of cities can be defined as: communicational flow of a set of adjustment capacities with a positive process of performance and adjustment after turbulence (33).

In addition, resilience of cities against incurred crises has two original introduced qualities. First, intrinsic quality that includes performances in normal conditions and time other than crisis; and second, adaptability in the time of crisis and flexibility when responding to the disaster, which can be used in cities' physical systems, such as infrastructures and social and / or economic systems, such as institutions and organizations.

Table 2. Definitions of resilience of cities and their characteristics

\begin{tabular}{|c|c|c|}
\hline Year & Definition of resilience & $\begin{array}{c}\text { Characteristics of } \\
\text { definitions }\end{array}$ \\
\hline 2007 & $\begin{array}{l}\text { Resiliency is the degree that the system is able to tolerate and not } \\
\text { being disintegrated before reorganizing (34). }\end{array}$ & $\begin{array}{l}\text { Capacity to tolerate before } \\
\text { disintegration }\end{array}$ \\
\hline 2008 & $\begin{array}{c}\text { Resilience is a process that causes the relationship between } \\
\text { adaptive capacities with response and changes after the } \\
\text { occurrence of side effects (35). }\end{array}$ & $\begin{array}{l}\text { Reciprocating relationship } \\
\text { between components }\end{array}$ \\
\hline 2009 & $\begin{array}{c}\text { Resiliency is a descriptive concept that gives us an insight about } \\
\text { the dynamic properties of system (36). }\end{array}$ & Dynamism \\
\hline 2010 & $\begin{array}{l}\text { Resilience dynamic and interactive and ever-changing process } \\
\text { between the individual and the environment (37). }\end{array}$ & Dynamic and changeable \\
\hline 2011 & $\begin{array}{l}\text { Resilience capacity and ability of cities to resist against shock, to } \\
\text { be survived, adapt, achieve balance after the occurrence of crisis } \\
\text { and rapid passing it (38) }\end{array}$ & Capacity to accept Change \\
\hline 2012 & $\begin{array}{l}\text { Resilience is a concept indicating the capacity of cities and } \\
\text { economies to adapt to shock when encountering with crisis, the } \\
\text { capacity to resist against shock and disturbances with minimal } \\
\text { disturbances in the system's performance (39) }\end{array}$ & Capacity to accept Change \\
\hline 2013 & $\begin{array}{l}\text { Resilience of cities is the ability to predict the risk and } \\
\text { occurrence of disaster, limited effects and return to the situation } \\
\text { before the crisis with safe, adjustment, transition and growth } \\
\text { when encountering with change (40). }\end{array}$ & Ability to cope with crisis \\
\hline
\end{tabular}

\section{Principles and characteristics of resilient cities}

Principled observance and preparation of strategies are needed for better efficiency of a great system, such as city and make it resilient and achieving to resilient city. The most important 
principles of resilience from viewpoints of some well-known researchers in this field have been mentioned in Table (3). These principles can be used to take step to create a resilient city and provide appropriate strategies in order to increase resilience of cities.

Table 3. Principles of resilient cities

\begin{tabular}{|c|c|c|}
\hline Schmidt and Gardlnd (2012) & Walker and et al (2004) & Gadzchak (2003) \\
\hline (41) & $(34)$ & (23) \\
\hline Maintaining Performance & Self-organization & Separation and dependency \\
\hline Being long-term of process & Variety & Strength and flexibility \\
\hline Ability to learn and adapt & Proper responding & Autonomy and collaboration \\
\hline $\begin{array}{c}\text { Resiliency as dimension opposed to } \\
\text { vulnerability }\end{array}$ & Participation & Planning and adjustment \\
\hline & Overcapacity & \\
\hline
\end{tabular}

A city will be considered fully resilient when all indices, components and dimensions of resilience in that city to be placed in a better situation and in growth and promotion mode. Perhaps an uneven promotion of different dimensions in the route of urban resilience will not much be led to the overall resilience of a city and its people. Leading social - economic dimension as the dimension that has the most relationship with people and citizens is very important in resilience of cities, but is not sufficient in any way and should not cause neglect of planners and experts to help promoting the situation, and improving other dimensions in the route of resilience of cities.

Cities can be among resilient cities when they have sensible, balanced, and close growth in all dimensions. Characteristics that can lead cities in moving toward the balanced growth in all dimensions of resilience have been described in Table (4). 
Table 4. Characteristics of resilient cities

\begin{tabular}{|c|c|c|c|c|}
\hline Row & Component & Concept & Promoting factors & Goal \\
\hline 1 & Effectuation & $\begin{array}{l}\text { Reliable and validated, } \\
\text { tolerant, being reliable }\end{array}$ & $\begin{array}{l}\text { the systems having safety and } \\
\text { protective factors against } \\
\text { shocks, the capability to } \\
\text { change the chain of decision- } \\
\text { making in encountering with } \\
\text { crisis }\end{array}$ & $\begin{array}{c}\text { Prevent } \\
\text { transmission of } \\
\text { damage to other } \\
\text { sectors }\end{array}$ \\
\hline 2 & Redundancy & $\begin{array}{l}\text { Having overcapacity } \\
\text { and appropriate } \\
\text { precautionary reserve }\end{array}$ & $\begin{array}{c}\text { Having overcapacity in } \\
\text { sensitive infrastructures and } \\
\text { equipped with a variety of } \\
\text { strategies and guidelines to } \\
\text { solve a problem }\end{array}$ & $\begin{array}{l}\text { Maintaining } \\
\text { system's } \\
\text { performance }\end{array}$ \\
\hline 3 & $\begin{array}{l}\text { Consciousness and } \\
\text { being wise }\end{array}$ & $\begin{array}{l}\text { Ability to adapt and } \\
\text { having a precaution }\end{array}$ & $\begin{array}{l}\text { Increase of trust in the } \\
\text { system; and components } \\
\text { being able to self- } \\
\text { organization }\end{array}$ & $\begin{array}{l}\text { Getting preparation } \\
\text { for compatibility } \\
\text { and revival }\end{array}$ \\
\hline 4 & $\begin{array}{l}\text { Responding to } \\
\text { hazard }\end{array}$ & $\begin{array}{l}\text { Ability of community to } \\
\text { move quickly, ability to } \\
\text { decide to reorganize in } \\
\text { specific time in times } \\
\text { of crisis }\end{array}$ & $\begin{array}{l}((\text { effective despatch })) \text { and } \\
\text { ((inclusive participation)) }\end{array}$ & $\begin{array}{l}\text { compatibility } \\
\text { toward new } \\
\text { conditions }\end{array}$ \\
\hline 5 & Revival & $\begin{array}{l}\text { Adaptability, } \\
\text { correct the situation } \\
\text { and rehabilitation }\end{array}$ & $\begin{array}{l}\text { Increasing of capacities } \\
\text { and strengthening } \\
\text { strategies, promotion of } \\
\text { information and } \\
\text { knowledge in applying } \\
\text { public and business } \\
\text { policies, and the ability } \\
\text { of decision makers to be } \\
\text { upgraded toward } \\
\text { changes in } \\
\text { environmental } \\
\text { conditions knowledge } \\
\text { vacuity of discover and } \\
\text { then organizing } \\
\text { researches to fill the } \\
\text { mentioned vacuities }\end{array}$ & $\begin{array}{l}\text { Returning the } \\
\text { system to its } \\
\text { normal } \\
\text { performance } \\
\text { after the } \\
\text { occurrence of } \\
\text { crisis }\end{array}$ \\
\hline
\end{tabular}

(42)

Several main characteristics can be mentioned for resilient cities according to the above discussion:

Firstly: ability to tolerate shocks and strokes caused by a risk in a way that those risks do not become a disaster. Thus it reduces the probability of failure.

Secondly: ability to return after disaster (therefore it can reduce the consequences of failure).

Thirdly: possibility and opportunity to change and accept after disaster, therefore, it reduces time required for recovery, and also the amount of vulnerability. 


\section{Social resilience}

All definitions of social resilience have somehow dealt to topic of social institutions, people, organizations or communities and their ability or capacity to tolerate, absorption, cope and regulation of the environmental and social threats against all kinds of threats (43).

The first definition of social resilience was posed by Adgr (2000). He defined social resilience as the ability of human communities to tolerate unexpected external events or disorders existing in infrastructure such as environmental changes, or severe social, economic, political changes, as well as the ability of these communities to recover such disorders.

Social resilience is measured by organizational and economic structures change factors, rights related to belongings, access to resources, and demographic changes (44). A resilient city is able to react positively to changes and / or stresses and is able to maintain its main performance as a community primary despite stresses. A particular change can be widely different results in different communities. Different communities will show different degrees of resilience toward the change (45).

Lorenz et al., believe that three types of capacity should be considered to define the concept of social resilience: 1- Coping capacities, 2- Adaptive capacities, and 3- Transformation capacities (46).

The main objective of social resilience is the promotion of capacity and skill of people, groups, and organizations in encountering with disturbance (47).

According to the view of Maguire and Hagan (2007), disasters' management plans should understand the capacity of a community for social resilience and rely on it. Social resilience is the capacity of social groups and communities in being recovered or giving positive response to the disasters (48).

According to the opinion of Pouli et al., (2006) resilience of a community toward disasters should not be considered a separate capability. This is because relatively simple communities contain different social groups that these groups are different from each other in different ways (49). Buckley et al., (2000) believe in this regard that the groups may be different in terms of social - economic status, level of geographic isolation or vulnerability toward psychological problems. These differences mean that different groups within a community 
can be more or less resilient toward a disaster (25). Vulnerable social groups (such as the elderly, children or the poor) may have fewer resources to adapt to the disaster.

According to Ogezfam's opinion (2005), we must understand the effects of disasters on specific groups for understanding the social effects of disasters and management and prevention of negative consequences (50). Identification of points of potential failure or social gaps within a community is also very important. Perhaps future failures in resilience toward disasters can be predicted and preventive measures can be designed through this affair.

Social resilience like individual resilience must consider economic, organizational, social and ecological dimensions of community. Resilience of community stability is related to stability and sustainability of environment. Displacement of population can be a sign of instability of the community or vice versa stability of population can be the result of stability of the community (51) when the population is placed under extreme pressures. For example, the effect of a natural disaster, displacement, and migration is one of the sign of social resilience failure, and social, economic, and demographic factors affect it (52).

Buckley (2007) in a study on new approaches on social resilience and vulnerability mentions factors that support people, households, groups and local communities against reducing disasters' effects. He believes collection of these factors increases the level of social resilience across the communities (Table 5). 
Table 5. Components and characteristics of social resiliency

\begin{tabular}{|c|c|}
\hline Components & Characteristics \\
\hline $\begin{array}{l}\text { Division of goals, } \\
\text { wishes and values } \\
\text { of the local } \\
\text { community }\end{array}$ & $\begin{array}{l}\text { Include contributing positive attitude to future, commitment to the local } \\
\text { community as a whole and agreed with local community's goals, such as } \\
\text { cultural partnerships. }\end{array}$ \\
\hline $\begin{array}{l}\text { Establishment of } \\
\text { social } \\
\text { infrastructures }\end{array}$ & $\begin{array}{l}\text { Such as channels of information, social networks and organizations of local } \\
\text { community. }\end{array}$ \\
\hline $\begin{array}{l}\text { Positive economic } \\
\text { and social } \\
\text { tendencies }\end{array}$ & Such as growing or stable population, healthy economic bases \\
\hline $\begin{array}{l}\text { Sustainability of } \\
\text { economic and } \\
\text { social life }\end{array}$ & Including the capacity for local community to cope with hazards \\
\hline Collaboration & $\begin{array}{l}\text { Collaboration between institutions, between local community groups, between } \\
\text { people and coordinated goals, which can achieve new innovations by sharing } \\
\text { skills, experiences, knowledge resources, and thinking about the same goals and } \\
\text { use it to increase capacities of preparation, prevention and coping with disasters. }\end{array}$ \\
\hline $\begin{array}{l}\text { Interests of local } \\
\text { community }\end{array}$ & $\begin{array}{l}\text { There may be a group that has social differences in a wider region, but has } \\
\text { common issues and interests, skills, or expertise. Such as religious interests, } \\
\text { group culture }\end{array}$ \\
\hline $\begin{array}{l}\text { Network } \\
\text { established }\end{array}$ & $\begin{array}{c}\text { Agreed and stable networks between people and groups facilitate the exchange } \\
\text { of information and sharing of resources and raise commitment of skills, time } \\
\text { and efforts for planning and preparation. }\end{array}$ \\
\hline $\begin{array}{l}\text { Resources and } \\
\text { skills }\end{array}$ & $\begin{array}{c}\text { Local available resources and skills may be directly related with emergency } \\
\text { management planning, and follow support of local community in the event of a } \\
\text { state of emergency. These may be as a variety of resources, skills, and cost of } \\
\text { using them, capability of existence local. }\end{array}$ \\
\hline
\end{tabular}

With globalization of immigration phenomenon and the increase of urbanization trend, the communities should review the way to achieve frequency and social resilience to reduce disasters' risk. Religious boards, neighbors, residents of high-rise buildings and residential complexes, and so on, can provide redundancy required for social resilience. Similarly, most companies and organizations depend on people to work and earnings. It is therefore logical that these organizations to precipitate in the process of promotion of social resilience.

Offering a higher level of frequency to prevent and reduce the risk of hazards reduces the number of people merely dependent on governments and charitable organizations to help and care. Therefore, it provides more efficiency in responding to hazards. The biggest obstacle in 
implementing a plan to promote social resilience is to obtain collaboration and cooperation with all factors or stakeholders that together create frequency matrix (54).

Thus increase of the ability of a city is to increase the ability and content of the internal communications between people, organizations and the environment that forms that city. Getting away from the philosophy of independence and acceptance of codependency culture is the key of coordination and development (43). The necessity of social resilience is not merely strengthening the independence but also is strengthening codependency.

In conclusion of the above definitions, social resilience can be defined based on three important characteristics:

1. Tolerance in encountering with sudden hazards.

2. Adaptability to changes (modification and response to environmental changes).

3. Returning to appropriate balance (previous and / or new) or the ability to return to normal mode within a specific time after the crisis, so that the system continuously to have maintained its previous performance. What is certain is the return to normal mode to be taken place faster and in less time in resilient systems (depending on environmental conditions, capacities and the degree of flexibility).

\section{Economic resilience}

Natural hazards have also economic consequences in addition to human damages, which affect human well-being. From another viewpoint, natural calamity can be defined as a natural crisis when causes turbulence in economic system's performance and negative effects on assets, factors of production, output, employment or consumers (55). When an event occurs, the effects of the disturbance in the economic system are in a way that is beyond immediate financial losses and expenses that we can replace them easily.

In addition it will follow consequences, such as damage to export and productions, damage to earnings and livelihood, rationing in some sectors, declining employment and reduction of tax returns. Calculation of the mentioned human detriments and losses is essential to estimate disaster effects on human well-being (56). Accordingly, one of the important ways to reduce vulnerability and damages and improve and critical situation in cities is paying attention to the topic of resilience.

Resilience has four roles in the economic literature. Its general concept is to study an economy against economic shocks. The main focus in ecological economy is on the analysis 
of the desired characteristics in order to achieve sustainable development. Resilience has been widely accepted in economic literature as a vague concept (57).

Economic resilience can be defined as the ability of an entity or a system with maintaining performances at the time of disturbance (58). Allocation of resources in the region hit by disaster is the main problem of economy in times of hazards occurrence. A more general definition includes dynamic considerations in defining economic resilience, including speed of an entity or a system from hard disturbances to achieve a desired status. This dimension of resilience (economic) resilience is more complicated than other dimensions (social, technical, environmental). This is because long-term investment related with work reconstruction is very difficult and is considered unique stage after disorder disturbance (59).

Martin et al., (2014) in an attempt to determine the concept of economic resilience in cities have offered four interpretations:

Resilience is: performance and resilient form following a disturbance.

Resilience is considered as "return" to the situation before the shock or the route of "recovery speed".

Resiliency is as the ability to absorb disturbances and stability of performances and structures.

Resilience is as "resistance" capacity of holding main performances of the system through adjustment of performances and structures.

However, each of the above-mentioned definitions refers to return to normal status, rather than adaption or fundamental change in response to changes (56).

According to Rose's view (2013), economic resilience is the ability of an economy or a city to minimize detriments and losses caused by a disaster (60). The purpose of many of the programs, including second millennium development goals, sustainable development, and second phase of Hyogo Framework, definition and measurement of appropriate indices for determining levels of economic resilience of regions.

Greenham et al., (2013) have defined resiliency as dynamic adaption. This definition is more comprehensive than economic resilience in which not only short-term and long-term economic changes but also environmental and social area changes have been included.

Greenham et al., have described economic resilience based on the following features.

- Business responsibility

- Flow of resources and money

- Basic asset and the ability of environment 
- Accountability of public sector and private companies

- Strong community and civil liberty

- Interdependence

- Sustainable development (61).

Economic harms are one of the consequences of natural disasters and have a close relationship with development, poverty and economic growth. Low-income countries see a lot of economic harms against natural disasters. Damage to properties, public infrastructures and long-term productivity are a result of natural disasters. Economic resilience is of development goals of communities toward empowerment against disturbances (62).

In a developed economy, the primary effect of shock has less depth. Economic recovery is done faster, according to investment to reduce risk and preparedness against hazards. But in developing countries, the effect of shock is larger and longer and economic recovery is done slower (55). In richer communities, presence of financial reserves, social security networks and insurance mechanism increase the speed of recovery after the shock (63).

Investment improves public services (health, education and welfare), sectional and infrastructures' development (roads, information and communications technology (ICT) and energy in regional and national scale (64). For example, poor communities are more dependent on natural assets, climate and sectors such as agriculture and fishing. These countries have less investment ability. While more than $40 \%$ of economic losses caused by natural hazards in developing countries are covered by insurance (65).

Diagram 1. Outline of effect of a disaster in a developed economy (green) and a developing

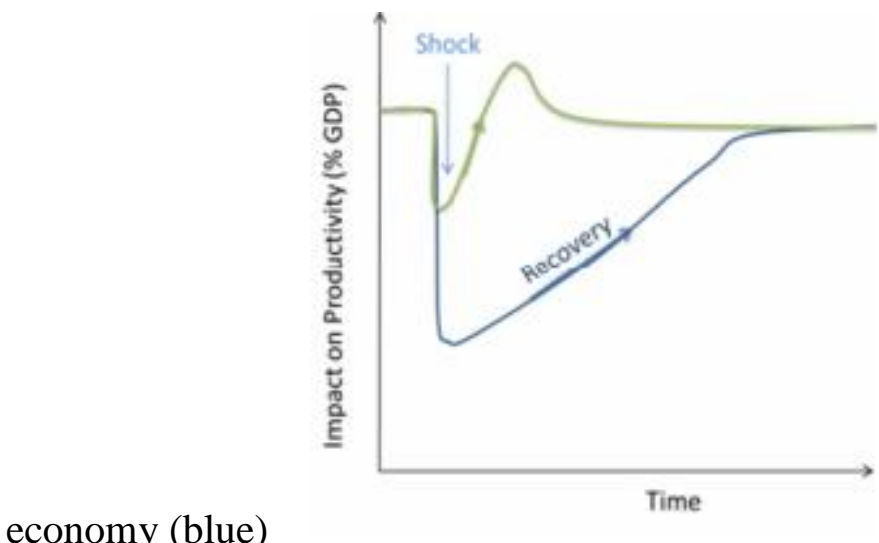

\section{CONCLUSION}

Despite the passage of more than three decades of conducting basic researches on urban resilience, this concept still lacks a comprehensive and operational understanding in various 
scientific fields, including disasters management. Most of the existing contradictions over the meaning of urban resilience are caused by cognitive tendencies, methodological methods, and the existing basic conceptual differences, as well as viewpoints that focus on research in ecological, social systems or a combination of both of them.

The presented definitions include a sustainable route of healthy performance after the occurrence of a natural disaster, a conscious effort to move forward in an enlightened and unified method and an experience obtained from a bad situation, capacity of a dynamic system for successful adaption, disturbances that threaten survival of a city and its growth, and a process to harness resources at the time of occurrence of disasters event of accidents in order to maintain well-being.

So it is important in the definition of resilience of cities to specify resilience as a trait, a process and consequence. This is often tempting to pay attention to this dual approach whether there is resilience or not, while there are various degrees of resilience in cities in different domains of life (66).

All definitions emphasize on the importance of continuing researches toward creating experimental, operational definitions of resilience, recognizing resilience as a complex structure in which people, families, organizations have various degrees of resilience based on spatial and temporal conditions, as well as the level of progress and culture of cities. Resilience is also different from a person to the other person based on the personality, available resources, and environmental context in cities.

Several main features can be considered for resilient cities according to the above discussion: Firstly: ability to tolerate shocks and strokes caused by a risk in a way that those risks do not become a disaster. Thus it reduces the probability of failure.

Secondly: ability to return after disaster (therefore it can reduce the consequences of failure). Thirdly: possibility and opportunity to change and accept after disaster, therefore, it reduces time required for recovery, and also the amount of vulnerability.

As we know, city will be considered fully resilient when all indices, components and dimensions of resilience in that city to be placed in a better situation and in growth and promotion mode. Perhaps an uneven promotion of different dimensions in the route of urban resilience will not much be led to the overall resilience of a city and its people. Leading social - economic dimension as the dimension that has the most relationship with people and citizens is very important in resilience of cities, but is not sufficient in any way and should not cause neglect of planners and experts to help promoting the situation, and improving other dimensions in the route of resilience of cities. 
Cities can be among resilient cities when they have sensible, balanced, and close growth in all dimensions.

If we introduce a city as a living creature, and accept growth, change, and dynamism of cities and their citizens, it is seldom possible to find and even build a city across the world that has completely components and indices of resilience. But the important issue is the will and levitation of these cities and their urban management, and their step-by-step movement toward ready cities and being closer to resilient cities. It is hoped that Iran cities utilize the mentioned guidelines more than ever by adding specific and aboriginal indices of resilience of Iranian, Islamic cities to those factors in order to realize this importance.

\section{REFERENCES}

[1] Adger-WN., Hodbod-J., 6 Ecological and social resilience. Handbook of sustainable development. 2014:91.

[2] Davis-I., Izadkhah-YO. Tsunami early warning system (EWS) and its integration within the chain of seismic safety. Disaster Prevention and Management: An International Journal. 2008; 17(2):281-91.

[3] Asghar Pourezzat-A., Nejati-M., Mollaee-A., Dataflow model for managing urban disasters: the experience of Bam earthquake. International Journal of Disaster Resilience in the Built Environment. 2010; 1(1):84-102.

[4] Chang-C-L., Lee-RC-T., Symbolic logic and mechanical theorem proving: Academic press; 2014.

[5] Laframboise-N., Loko-B., Natural disasters: mitigating impact, managing risks. 2012.

[6] Berkes-F., Community-based conservation in a globalized world. Proceedings of the National academy of sciences. 2007; 104(39):15188-93.

[7] Pelling-M., The vulnerability of cities: natural disasters and social resilience: Earthscan; 2012.

[8] MandinP., COMMENTARY_ETHICS AND REFLECTING PROCESSES. Journal of Social Work Practice. 2007; 21(2):235-8.

[9] Manyena-SB., Disaster resilience: A question of 'multiple faces' and 'multiple spaces'? International Journal of Disaster Risk Reduction. 2014; 8:1-9.

[10] Wikström-A., the Challenge of Change: Planning for social urban resilience. An analysis of contemporary planning aims and practices. 2013. 
[11] Andersen-LE., Cardona-M., Building resilience against adverse shocks: What are the determinants of vulnerability and resilience? Development Research Working Paper Series, 2013.

[12] Kamani-Fard-A., Hamdan Ahmad-M., Remaz Ossen-D., The sense of place in the new homes of post-Bam earthquake reconstruction. International Journal of Disaster Resilience in the Built Environment. 2012;3(3):220-36.

[13] Jabareen-Y., Towards a Sustainability Education Framework: Challenges, Concepts and Strategies-The Contribution from Urban Planning Perspectives. Sustainability. 2012;4(9):2247-69.

[14] Ainuddin S, Routray JK. Community resilience framework for an earthquake prone area in Baluchistan. International Journal of Disaster Risk Reduction. 2012;2:25-36.

[15] Alliance-R. Urban resilience research prospectus. Australia: CSIRO. 2007:2007-02.

[16] Folke-C., Carpenter-SR, Walker-B., Scheffer-M., Chapin-T., Rockstrom-J., Resilience thinking: integrating resilience, adaptability and transformability. 2010.

[17] Gutmann-A., Daniels-RJ., Kettl-DF., Kunreuther-H., On risk and disaster: Lessons from Hurricane Katrina: University of Pennsylvania Press; 2011.

[18] Arefi-M., Deconstructing placemaking: Needs, opportunities, and assets: Routledge; 2014.

[19] Marcuse-P., Kempen-Rv., Conclusion: a changed spatial order. Globalizing Cities: A New Spatial Order? 2000:249-75.

[20] Turner-MD. Political ecology I An alliance with resilience? Progress in Human Geography. 2013:0309132513502770.

[21] Leichenko-R., Climate change and urban resilience. Current opinion in environmental sustainability. 2011;3(3):164-8.

[22] Clark-J., Huang-H-I., Walsh-JP., A typology of 'innovation districts': what it means for regional resilience. Cambridge Journal of Regions, Economy and Society. 2010; 3(1):121-37. [23] Godschalk-DR., Urban hazard mitigation: creating resilient cities. Natural hazards review. 2003; 4(3):136-43.

[24] Holling-CS., Engineering resilience versus ecological resilience. Engineering within ecological constraints. 1996; 31:32.

[25] Buckle-P., Mars-G., Smale-S., New approaches to assessing vulnerability and resilience. Australian Journal of Emergency Management, The. 2000; 15(2):8.

[26] Gunderson-LH., Holling-C., Pritchard-L., Peterson-GD., Resilience of large-scale resource systems. SCOPE-SCIENTIFIC COMMITTEE ON PROBLEMS OF THE 
ENVIRONMENT INTERNATIONAL COUNCIL OF SCIENTIFIC UNIONS. 2002; 60:320.

[27] Cardona-OD., Hurtado-JE., Chardon-AC., editors. Indicators for disaster risk management. First expert meeting on disaster risk conceptualization and indicator modelling Manizales; 2003.

[28] Manyena SB. The concept of resilience revisited. Disasters. 2006; 30(4):434-50.

[29] Cutter-SL., Burton-CG., Emrich-CT., Disaster resilience indicators for benchmarking baseline conditions. Journal of Homeland Security and Emergency Management. 2010; 7(1).

[30] Birkmann-J., Cardona-O., Carreño-M., Barbat-A., Pelling-M., Schneiderbauer-S., et al. Framing vulnerability, risk and societal responses: the MOVE framework. Natural hazards. 2013; 67(2):193-211.

[31] Kärrholm-M., Nylund-K., de la Fuente PP. Spatial resilience and urban planning: Addressing the interdependence of urban retail areas. Cities. 2014;36:121-30.

[32] Hodson-M., Marvin-S., After sustainable cities?: Routledge; 2014.

[33] Norris FH, Stevens SP. Community resilience and the principles of mass trauma intervention. Psychiatry. 2007;70(4):320-8.

[34] Walker-B., Holling-CS., Carpenter-SR., Kinzig-A., Resilience, adaptability and transformability in social--ecological systems. Ecology and society. 2004;9(2):5.

[35] Norris-FH., Stevens-SP., Pfefferbaum-B., Wyche-KF., Pfefferbaum-RL. Community resilience as a metaphor, theory, set of capacities, and strategy for disaster readiness. American journal of community psychology. 2008;41(1-2):127-50.

[36] Derissen-S., Quaas-M., Baumgärtner-S. The relationship between resilience and sustainable development of ecological-economic systems. University of Lüneburg Working Paper Series in Economics, 2009.

[37] Pooley-JA., Cohen L. Resilience: A definition in context. Australian Community Psychologist. 2010;22(1):30-7.

[38] Matsuoka-Y, Shaw-R. Linking resilience planning to Hyogo framework for action in cities. Climate and disaster resilience in cities Community, environment and disaster risk management. 2011;6:129-47.

[39] UNESCAP-A. UNEP (2012). Green growth, resources and resilience environmental sustainability in Asia and the Pacific, Bangkok.

[40] Martin-AJ. Academic buoyancy and academic resilience: Exploring 'everyday'and 'classic'resilience in the face of academic adversity. School Psychology International. 2013;34(5):488-500. 
[41] Schmidt-DH, Garland-KA. Bone dry in Texas: resilience to drought on the upper Texas Gulf Coast. Journal of Planning Literature. 2012:0885412212454013.

[42] McEntire-DA. Disaster response and recovery: strategies and tactics for resilience: John Wiley \& Sons; 2014.

[43] Keck-M, Sakdapolrak P. What is social resilience? Lessons learned and ways forward. Erdkunde. 2013:5-19.

[44] Adger-WN. Social and ecological resilience: are they related? Progress in human geography. 2000;24(3):347-64.

[45] Béné-C, Wood-RG, Newsham-A, Davies-M. Resilience: new utopia or new tyranny? Reflection about the potentials and limits of the concept of resilience in relation to vulnerability reduction programmes. IDS Working Papers. 2012;2012(405):1-61.

[46] Lorenz-DF. The diversity of resilience: contributions from a social science perspective. Natural Hazards. 2013;67(1):7-24.

[47] Obrist-B, Pfeiffer-C, Henley-R. Multi-layered social resilience a new approach in mitigation research. Progress in Development Studies. 2010;10(4):283-93.

[48] Maguire-B, Hagan-P. Disasters and communities: understanding social resilience. 2007.

[49] Pooley-JA., Cohen-L., O'Connor-M., Links between community and individual resilience: Evidence from cyclone affected communities in North West Australia. Disaster resilience: An integrated approach. 2006:161-70.

[50] Oxfam-G., Corsellis-T., Vitale-A., Transitional settlement: displaced populations: Oxfam; 2005.

[51] Boon-HJ., Cottrell-A., King-D., Stevenson-RB., Millar-J. Bronfenbrenner's bioecological theory for modelling community resilience to natural disasters. Natural Hazards. 2012;60(2):381-408.

[52] Garschagen-M., Renaud-FG., Birkmann-J., Dynamic resilience of peri-urban agriculturalists in the Mekong Delta under pressures of socio-economic transformation and climate change. Environmental change and agricultural sustainability in the Mekong Delta: Springer; 2011. p. 141-63.

[53] Buckle-P., Assessing social resilience. Disaster resilience: An integrated approach. 2006:88-103.

[54] Skerratt S. Enhancing the analysis of rural community resilience: evidence from community land ownership. Journal of Rural Studies. 2013;31:36-46.

[55] Hallegatte-S., Economic Resilience: definition and measurement. World Bank Policy Research Working Paper. 2014 (6852). 
[56] Martin R, Sunley P. On the notion of regional economic resilience: conceptualization and explanation. Journal of Economic Geography. 2015;15(1):1-42.

[57] Perrings-C., Resilience and sustainable development. Environment and Development Economics. 2006;11(04):417-27.

[58] Rose-A., Defining and measuring economic resilience to disasters. Disaster Prevention and Management: An International Journal. 2004;13(4):307-14.

[59] Nelson-AC., Miller-M., Ganning-JP., Stoker-P., Liu-JH., Ewing-R., editors. Transit and Economic Resilience. Transportation Research Board 94th Annual Meeting; 2015.

[60] Rose-A., Krausmann-E., An economic framework for the development of a resilience index for business recovery. International Journal of Disaster Risk Reduction. 2013;5:73-83.

[61] Greenham-T., Cox-E., Ryan-Collins-J., Mapping Economic Resilience. York: Friends Provident Foundation. 2013.

[62] Briguglio-L., Cordina-G., Farrugia-N., Vella-S., Profiling economic vulnerability and resilience in small states: conceptual underpinnings. Islands and Small States Institute of the University of Malta. 2008.

[63] Gurenko-E., Lester-R., Mahul-O., Gonulal-SO., Earthquake Insurance in Turkey. The World Bank. 2006.

[64] Bank-W. World development indicators. World Bank. 2010.

[65] Hallegatte-S., Heal-G., Fay-M., Treguer-D. From growth to green growth-a framework. National Bureau of Economic Research, 2012.

[65] Southwick-SM., Pietrzak-RH., White-G. Interventions to enhance resilience and resilience-related constructs in adults. Resilience and mental health: Challenges across the lifespan. 2011:289-306.

\section{How to cite this article:}

Rezaei M R, Nia A B. Evaluation of dimensions, approaches and concepts of resilience in urban societies with an emphasis on natural disasters . J. Fundam. Appl. Sci., 2016, 8(2S), 1630-1649. 